\title{
油脂加工技術の開発動向
}

\section{Recent Development of Fat Modification Process}

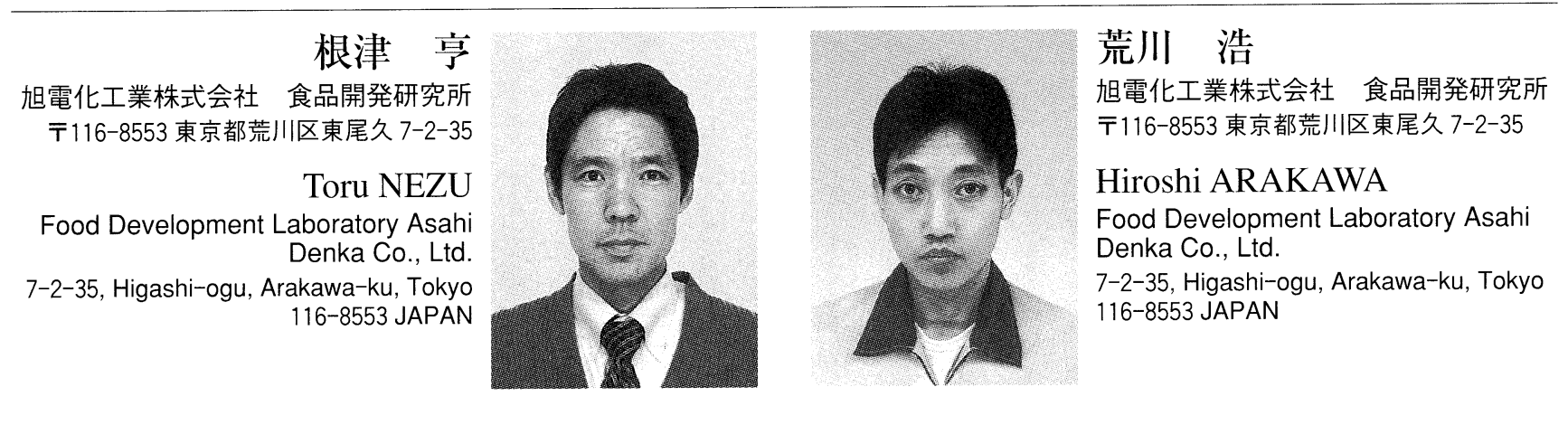

論文要旨：近年のトランス酸の栄養問題や環境保全への関心の高まり，そしてパーム油生産量の拡大は， 油脂加工技術の研究開発動向に大きな影響を及ぼしていると思われる。本総説では新たな展開として注目さ れる低トランス水素添加，ドライ分別，酵素法エステル交換の最近の開発動向を中心に解説する。

\section{1 はじめに}

マーガリンやショートニングには，用途によってさま ざまな物性が要求されるが, 牛脂やラード, パーム油等 の天然固形脂で得られる物性は限られているため, 油脂 を加工することが行われている。現在, 工業的に実施さ れている油脂の加工方法として，水素添加（硬化）, 工 ステル交換，分別がある。いずれも古くから知られてい る方法であり，水素添加は 1903 年の Norman の英国特 許, エステル交換は 1924 年のVan Loonの英国特許, 分別に至っては 1886 年のマーガリンの発明で有名な Mega-Mouries のフランス特許までさかのぼれるとい $j^{1)}$ 。

わが国においては，1913 年に工業規模での魚油の硬 化が開始されている ${ }^{2)}$ 。Fig. 1 に示す国内生産数量 ${ }^{3)}$ から 分かるように, 日本の油脂加工は水素添加が中心であっ た。しかし，1990年代以降の（1）魚油生産量の減少, （2）天然固形脂であるパーム油生産量の拡大，（3）トラ

連絡者: 根津 亨

E-mail : t-nezu@adk.co.jp
ンス酸の栄養問題への関心，(4）環境への関心の高まり は，水素添加を中心としたこれまでの油脂加工技術に大 きな影響を及ぼすと思われる。

水素添加, エステル交換, 分別それぞれに関する総合 的な解説は, 本誌上で高橋と依田 ${ }^{6)}$, 松本 ${ }^{7)}$, 阿部島 ${ }^{8)}$ が 取り上げているため，ここでは最近の技術開発動向を中

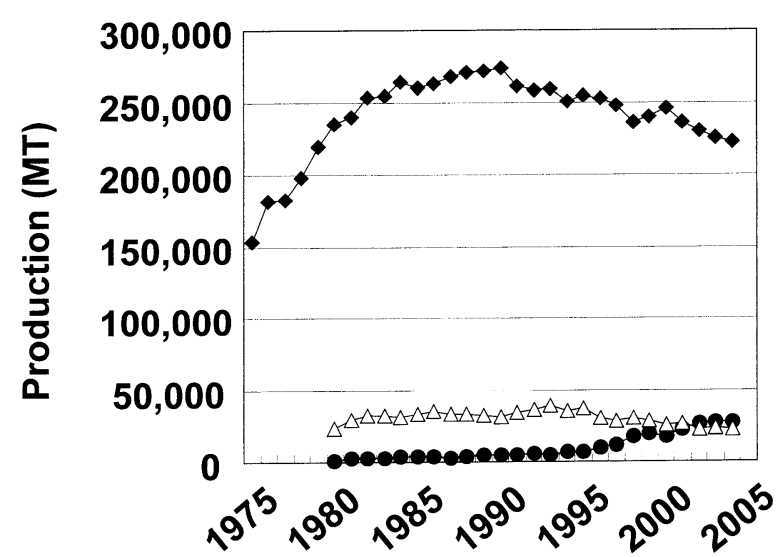

Fig. 1 Annual Production of Modified Fat in Japan.

$\bullet$ :Hydrogenated, $\bigcirc$ : Interesterified, $\triangle$ : Fractionated 
心に解説する。

\section{2 水素添加（硬化）}

油脂の水素添加は，ニッケル（Ni）等の触媒存在下， 油脂と水素を接触させて行われ，脂肪酸の二重結合への 水素添加と二重結合の異性化によるトランス酸生成が起 こる。硬化油の物性は水素添加の程度とトランス酸生成 量, 脂肪酸選択性によって決定され, 酸化安定性が高く 口溶けの良い固形脂を得るにはトリエン，ジエンが選択 的に水素添加され，融点の高いステアリン酸生成が少な く中間的な融点を持つトランス酸が生成することが望ま しい。またトランス酸を含有する油脂は，クリーミング 性に優れ，結晶形が $\beta$ プライム型で安定化しやすい等， マーガリン，ショートニング用の固形脂として優れた性 質を持っていることから広く利用されてきた7)。

一方で, 近年トランス酸の健康への影響が注目されて おり，1990年代後半からは，欧米を中心に加工油脂製 品に含有されるトランス酸を低減する動きが活発化し7), パーム油やエステル交換油を用いた低トランス製品が 開発されてきている ${ }^{8)}$ 。ここでは水素添加に関する最近 の技術開発動向として, 低トランス水素添加の研究動向 を取り上げる。

\section{$2 \cdot 1$ ニッケル触媒による低トランス水素添加}

トランス酸は，触媒表面で半水素化された反応中間体 が脱水素される際に生じると考えられている。従って, 低トランス化には，触媒表面の水素濃度を高めることが 有効であるが，この条件は脂肪酸選択性を低下させる条 件でもあり ${ }^{4)}$ ，低トランス化と高い脂肪酸選択性を雨立 させることが課題の一つである。

通常，ニッケル $(\mathrm{Ni})$ 触媒は，130 $230^{\circ} \mathrm{C}$ ，水素圧力 $0.5 \mathrm{MPa}$ 以下で用いられ，触媒の種類によるトランス酸 生成量の差はないと言われている。Eller ら ${ }^{10)}$ は Ni 触媒 を用いて大豆油を $140 \sim 170^{\circ} \mathrm{C} ， 1.4 \mathrm{MPa}$ で IV（ヨウ素 価） 70 まで反応した結果，一般的な条件にくらべてト ランス酸生成量が半減し，ステアリン酸生成量が約 2 倍 になったことを報告している。な拉，一般的な硬化条件 における大豆硬化油のトランス酸生成量とステアリン酸 生成量の関係はFig. 2 を参照していただきたい。

Hans ら ${ }^{11)}$ は， Ni 触媒を水素気流下， $200^{\circ} \mathrm{C}$ で 90 分間 活性化処理すると，30 $40^{\circ} \mathrm{C}$ 程度の低温で反応が可能に なり，この活性化触媒を用いて大豆油を $50^{\circ} \mathrm{C} ， 0.65 \mathrm{MPa}$ でIV 102 まで反応した結果，ステアリン酸生成量が増 加することなく，トランス酸生成量が 3 分の 1 に低下し たことを報告した。本方法は実用的な条件での水素添加 であり，詳細な報告が待たれる。

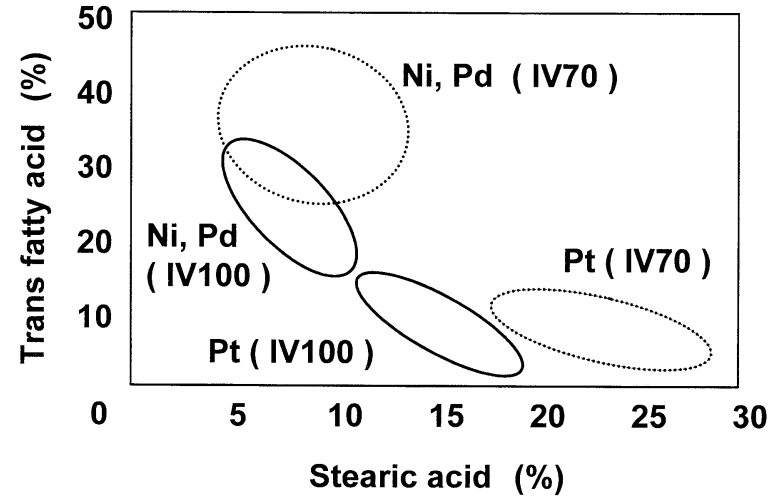

Fig. 2 Stearic Acid and trans Fatty Acid Content of Hydrogenated Soyabean Oil. ${ }^{13), 14)}$

\section{$2 \cdot 2$ 貴金属触媒による低トランス硬化}

貴金属触媒は Ni 触媒に比べて活性が高く室温, 常圧 で水素添加反応が進行するという特徵を持つ。貴金属触 媒では主にパラジウム $(\mathrm{Pd})$ 触媒とプラチナ $(\mathrm{Pt})$ 触媒 で検討が行われており，Pd 触媒は $\mathrm{Ni}$ 触媒と同等な脂肪 酸選択性とトランス酸生成量を示すこと, Pt 触媒はト ランス酸生成量が少ないが脂肪酸選択性が低いこと等が 知られていた (Fig. 2) ${ }^{12), 13), 14) 。 ~}$

低トランス化と脂肪酸選択性の両立を目的として貴金 属触媒の改良検討が行われており，Pd触媒をアミンで 修飾またはアミン存在下で反応する方法 ${ }^{15)}$. 16), 17), 鉛やコ バルトとの合金触媒とする方法等 ${ }^{6)}$ ).17)，18）で脂肪酸選択 性が向上し，トランス酸生成量が低下したという。また 最近, Engelhard 社はPt触媒で, 表面改質剂や特殊な ゼオライト担体を使用することで脂肪酸選択性が高めら れること ${ }^{19)}, \mathrm{Ni}$ 触媒や Pd 触媒と同程度の選択性を持つ Pt 触媒を開発したことを公表している ${ }^{14)}$

貴金属触媒を使用する上での最大の障害は触媒コスト である。パイロットプラントに拈て Pd 触媒を繰り返 し使用した結果，触媒量の 545,000 倍の油脂が処理できた

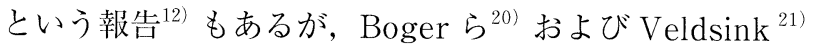
は，繰返しまたは連続使用による Pd 触媒の活性低下を 報告している。触媒の活性低下は, 従来から知られてい た原料油中の硫黄化合物等に加え, 硬化反応で副生する 一酸化炭素や有機溶剤不溶性の有機物（coke）の蓄積に

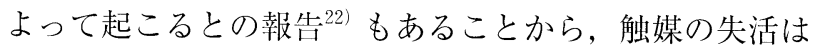
避けがたい面があり, 実用化に向けて, 触媒を回収し再 生する方法とその仕組みが課題となろう。

\section{$2 \cdot 3$ 新しい反応方法による低トランス水素添加}

1990 年代から研究がはじめられた新しい水素添加方 法について概要を紹介したい。

\section{$2 \cdot 3 \cdot 1$ 超臨界流体中での水素添加}

Harrod ${ }^{23)}$ は，超臨界状態にあるプロパンまたは二酸 
化炭素を溶媒として, 油脂と水素を均一に溶解してパラ ジウムを触媒として反応すると, 反応速度が極めて速 く，かつトランス酸生成量が低下することを報告した。 最近，Ramirez ${ }^{24)}$ は，ひまわり油の反応条件を詳細に 検討し, IV 95〜110 でトランス酸生成量 2〜 5\%，ステ アリン酸生成量 1〜3.3\%の硬化油が得られたことを報告 している。

\section{$2 \cdot 3 \cdot 2$ 電気化学的水素添加}

Y usem と Pintauro ${ }^{25)}$ は油脂と電解質水溶液を溶剂に 溶解し, 触媒を陽極として電気分解することで, 触媒表 面で水素を発生させ水素添加する方法を報告した。一 方, Smidnovik ら ${ }^{26)}$ は水素供与体としてギ酸などを用い て水素添加する方法を報告した。いずれも低温で反応で き，トランス酸生成量が抑制可能であった。最近， Mondal と Lalvani ${ }^{27)}$ はこれらを組合せ, 触媒表面で水 素供与体を発生させる方法を開発し, IV 100 の大豆硬化 油がトランス酸 $5 \%$, ステアリン酸 $8 \%$ 程度であったこ とを報告した。

\section{3 分別}

分別とは溶解した油脂を冷却して油脂中の高融点部分 を選択的に結晶化し, 結晶部と液状部に分離する方法で あり, 現在実用化されている分別方法には, ドライ分 別, 界面活性剂分別, 溶剂分別がある。中でもドライ分 別は, 工程がシンプルで低コスト, 環境に優しい “Green”なプロセスとして注目されており，パーム油お よび乳脂では特に重要な加工方法となっている ${ }^{28)}$ 。

従来, ドライ分別では, 純度の高い結晶を得ることや 結晶部を高収率で得ることが難しかったが, 最近はパー ム油等でスラリーの結晶量が 20〜30\%, 結晶部の収率 が $40 \%$ 以上にもなる分別が一般的に行われている。ま た従来, 溶剂分別でしか得られなかった高純度なパーム 中融点部をドライ分別で分画することもそれほど特殊な ことではなくなっているように思われる。

ドライ分別技術におけるキーポイントは結晶化であ り, 結晶析出量が多いほどろ過性が良く純度の高い結晶 を得ることが難しく，分別操作は困難になる。以下にド ライ分別に関わる最近の結晶化条件の研究および結晶化 装置の開発動向を述べる。

\section{$3 \cdot 1$ 結晶化条件の研究}

ドライ分別において十分な結晶化時間が与えられてい る場合，析出する結晶量は分別温度で決まるが，問題は 結晶をろ過に適した状態に調節することであり, ろ過に 至るまでの, 冷却速度 (過飽和度), 攪拌条件, 伝熱面 温度の影響等の影響が調べられている。

\section{$3 \cdot 1 \cdot 1$ 冷却速度の影響}

乳脂のドライ分別において Diffence ${ }^{29)}$ は, 冷却速度 が遅い方が小さくて均一な結晶が生成し, 純度の高い結 晶部が得られたことを報告したが, Herrera と Hartel ${ }^{30)}$ はDeffence と反対の結果を得ている。冷却速度には最 適値があると思われ，最適值を中心とした広い範囲での 検討が望まれるが, 冷却速度の調節が結晶状態をコント ロールするための有効な方法であることは明らかであ る。

\section{$3 \cdot 1 \cdot 2$ 攪拌速度の影響}

Herrera と Hartel ${ }^{30)}$ は高速で攪拌すると結晶核の発 生が促進され細かな結晶が生じ，低速で覺拌すると結晶 同士の凝集が進み不定形で大きな結晶が生じることを観 察した。Patience ${ }^{31)} も$ 同様な現象を観察しており, 比較的均一で球状の結晶が生成する条件でろ過抵抗が最 小となり，結晶部の純度が最大になったことを報告し た。しかし，この報告では，同一条件でもろ過抵抗に 10 倍程度の差があり，ドライ分別研究の難しさが判る。

\section{$3 \cdot 1 \cdot 3$ 伝熱面と油脂の温度差}

大規模な晶析槽では伝熱面と油脂相に温度差が生じ る。Hartel ら ${ }^{32)}$ は, 乳脂を一定の過飽和度で前処理後

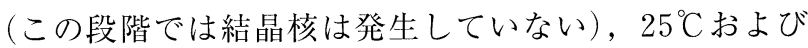
$27.5^{\circ} \mathrm{C}$ に温度を上げ，結晶核の発生速度を調べた結果， 結晶核発生速度は前処理の過飽和度が大きいほど速いこ とを報告した。この結果は晶析槽伝熱面での局所的な過 冷却が油脂全体の結晶核発生速度を高める可能性を示唆 している。

\section{$3 \cdot 1 \cdot 4$ ドライ分別における結晶化現象の実際}

Breitschuhと Folter ${ }^{33)}$ は, 乳脂の分別において, 最 初の結晶核が発生してから，ある程度まで結晶成長が進 行した後，新たな結晶核が発生し，さらに結晶化が進行 することを観察した。析出する結晶量が多い場合，多段 階で結晶化が進行する現象が生じやすく，各段について 適切な結晶化条件を設定すべきであるとした。Hartel ら ${ }^{34)}$ は結晶核発生段階と結晶成長段階を別々に制御する方法 を開示している。

筆者らは年) パームオレインのドライ分別において, 最 初に $\beta$ プライム型の結晶が析出し，その後，新たに $\beta$ 型 の結晶が析出することを観察した（Fig. 3）。結晶化温度 によって $\beta$ 型結晶の発生夕イミングとその状態が異な $り, \beta$ 型の結晶状態をコントロールすることが重要なポ イントであろうと考えている。

\section{$3 \cdot 2$ 結晶化装置の開発動向}

\section{$3 \cdot 2 \cdot 1$ 攪拌槽型晶析槽}

油脂の工業的分別装置として Tirtiaux 社, DeSmet 社 の分別装置が広く利用されている。Tirtiaux 社が大型の 


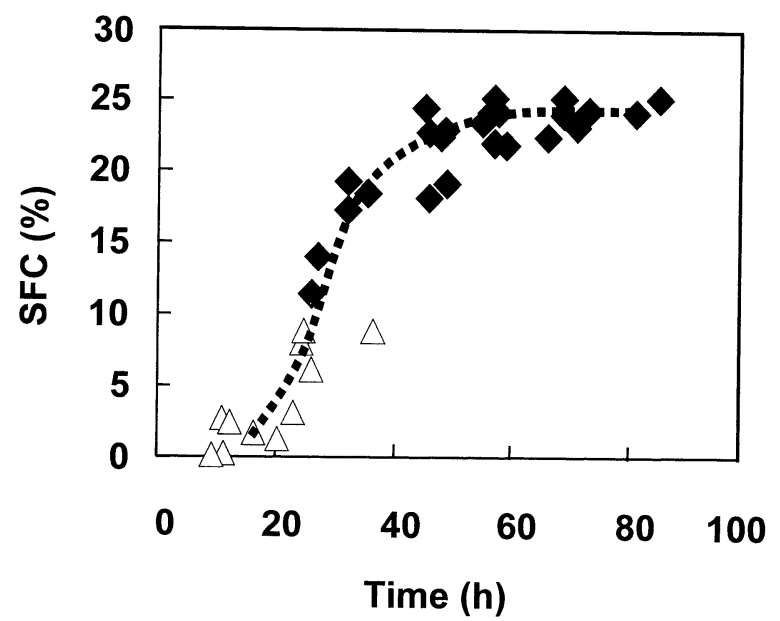

Fig. 3 Change of Solid Fat Content and Polymorphism during Palm Olein Dry Fractionation ${ }^{35)}$. $\triangle: \beta$-prime, $\diamond: \beta$-prime $+\beta$.

タンクに伝熱面をコイル状またはフィン状に配置し, 油 脂と一定の温度差を保つように冷却水をコントロールし ているのに対して，DeSmet 社は同心円状に伝熱面を配 置し，体積あたりの伝熱面積を大きく，攪拌羽根と伝熱 面のクリアランスを狭くすることによって伝熱効率を高 めていることが特徴である ${ }^{36)}$ 。

最近, Krupp 社は垂直に配列した冷却コイル自体を回 転させることで覺拌を行う晶析槽（STAR Crystallizer） を開発した ${ }^{37)}$ 。この方式は伝熱コイルの全面を等しく利 用できるため，総括伝熱係数が上記 2 社の 2 倍程度あ り，また，冷却コイルの回転半径が小さいため結晶への 機械的ストレスが小さく，パーム油分別において，従来 法に比べて結晶化時間が半減できることが報告されてい る。

\section{$3 \cdot 2 \cdot 2$ 静置晶析装置}

静置晶析は攪找による二次核の発生や結晶の凝集が生 じず，必ずしもスラリーが流動性を保っている必要がな いことから，微細結晶が発生しやすい油脂や多量に結晶 を発生させる分別に適している。しかし，結晶化したブ ロックをろ過機に導入する作業に人手を要することや， 伝熱効率が悪いため結晶化が遅く部位により結晶状態が バラつくなどの欠点があった。

桑原ら ${ }^{38)}$ は，静置下で結晶化したブロックを機械的に 解砕し，流動性のあるペーストにしてメンブレンフィル ターに導入する方法を，米田ら ${ }^{39)}$ は，これを改良して， 分別原料油脂にあらかじめ分別して得られた低融点部を 一定量混合後，予備冷却し，トレイに分注して静置下で 結晶化させる方法を開示した。この方法では分別原料油 脂が流動性を保ったまま結晶化されるため，伝熱効率が 高く，自動化が可能とのことである。
また，M. Hendrix ら ${ }^{40)}$ は，予備冷却し結晶が一部析 出したスラリーを，冷却面を持つチャンバー（フィル タープレス様の構造をもつ）にフィードし，静置状態で 結晶化後，開枠して結晶化したブロックを落下させ，解 砕，流動化してフィルタープレスに導入する方法を開

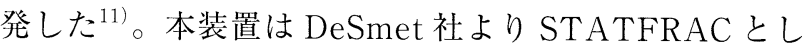
て実用化されている。

\section{$3 \cdot 2 \cdot 3$ Solid Phase 法}

これまで説明してきた結晶化方法が，結晶が液状部に 分散したサスペンジョンを形成しているのに対して，冷 却面に結晶を層状に形成させる方法を Solid Phase 法と いう。この方法の特徵は結晶化潜熱を，結晶層を通して 除去すること，および結晶化後の分離が結晶層を形成し た後，液状部を抜き出すことで行われることであり，乳脂 を中心にラードや牛脂での応用例が報告されている ${ }^{41,42)}$ 。

Solid Phase 法は結晶の表面積が狭いが，線成長速度 が速いため, 総括的な結晶化速度はサスペンション法と 同等になる ${ }^{42)}$ 。さらに液状部を排出後，結晶層を温めた 気流で表面を溶解，発汗させて結晶部の純度を向上させ る方法 ${ }^{42)}$ ，あらかじめ伝熱面に少量の結晶を付着させ結 晶化を促進する方法 ${ }^{43)}$ も報告されている。Solid Phase 法は，晶癖にとらわれにくいフレキシビリティーを持っ ており，今後，多段化等との組合せに等により有効な方 法となる可能性がある。

\section{4 エステル交換}

油脂のエステル交換は，(1)油脂の物理的性質の改質を 目的とした油脂同士または油脂と脂肪酸（エステル）の エステル交換反応と，(2)脂肪酸エステルの調製を目的と した油脂とアルコールのアルコリシス反応に大別される5)。 エステル交換油は，水素添加に比べて油脂のロスが大 きくコストがかかる方法であったため，その用途は限定 されたものであったが，近年のトランス酸の栄養問題等 により，硬化油に変わる油脂としてエステル交換油の重 要性が高まっている ${ }^{5), 7,8)}$ 。一方，脂肪酸エステルは，バ イオディーゼルとして注目されており，エステル交換は 食品, オレオケミカル両分野で活発な研究が行われてい る。ここでは，エステル交換油の製造プロセスとバイオ ディーゼルを目的としたアルコリシスについて最近の技 術動向を概観する。

\section{4·1 エステル交換による油脂の改質プロセス}

油脂間のエステル交換は，トリグリセリド中の脂肪酸 結合位置を再配列することにより，油脂の物理的性質を 改質する技術であり，ナトリウムメチラート等の化学触 媒を用いる化学法とリパーゼを触媒とする酵素法があ る。化学法ではトリグリセリド中の位置や脂肪酸種に関 
わらないランダムなエステル交換反応が生じるのに対し て, 酵素法は用いる酵素や反応条件によってランダム化 だけでなく 1,3 位特異的な反応や脂肪酸特異的なエステ ル交換反応が可能である。

近年利用が拡大しているパーム油は 2-オレオイルージ パルミチン（POP）を多く含むため結晶化速度が遅く SFC (Solid Fat Content) プロフィールが縦型で使いに くい等の問題があるが，ランダムエステル交換は，この ような欠点を改質することができ，パーム油を利用する 上で極めて有効な加工方法である。

\section{$4 \cdot 1 \cdot 1$ 化学法}

化学法では主にナトリウムメチラートが触媒として用 いられてきたが, 脂肪酸メチルエステルと石けんが副生 しロスとなるだけでなく, 反応後に石けん成分を水洗除 去する工程が必要となり, 環境負荷も高かった。化学法 では脱触媒プロセスを簡略化し排水負荷を軽減すること を目的として, 反応後に少量のクエン酸水溶液を添加, 中和後 (石鍢が脂肪酸になる), 活性白土を添加・脱水 する ${ }^{44)}$ 等の改良が行われている。

\section{$4 \cdot 1 \cdot 2$ 酵素法}

1976 年に Herder ら ${ }^{45)}$ は, 微生物リパーゼを珪藻土等 の担体に固定化し, 微量の水分存在下で油脂のエステル 交換を行う方法を開示した。その後，固定化リパーゼを 用いた酵素法は, 化学法では不可能な位置特異的な反応 や脂肪酸特異的な反応ができることに加え, より穏やか な条件で反応でき，副生物が少ない等の利点があること から多くの研究がなされてきた。固定化リパーゼに関し ては Malcata ${ }^{46)}$ らの総説があるので参照していただきた い。

固定化リパーゼはナトリウムメチラートに比べて高価 なため, 酵素法エステル交換の利用は, 高付加価值でリ パーゼ特有の特異性を生かした分野でスタートした。実 用化された例としては，(1) POP を主成分とするパーム 中融点部やトリオレイン（OOO）を主成分とするハイ オレイック油脂をステアリン酸（S）またはステアリン 酸エステルを 1,3 位特異的にエステル交換して 2 -オレオ イルーパルミトステアリン（POS）や2-オレオイル-ジス

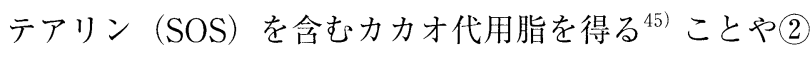
トリパルミチン (PPP) とオレイン酸を 1,3 位特異的に エステル交換して, OPO を含む消化吸収性に優れる乳 幼児用油脂を得ること敉がある。このような研究は現 在でも進められており, EPA やDHA を高濃度に含む油 脂の調製 ${ }^{48)}$, 共役リノール酸を高濃度に含む油脂の調 製 ${ }^{49 ）}$ 等，多くの報告がある。

一方, 近年, 活性が高く経済性に優れたリパーゼが開 発されており, 酵素法はロスが少なくシンプルな方法と

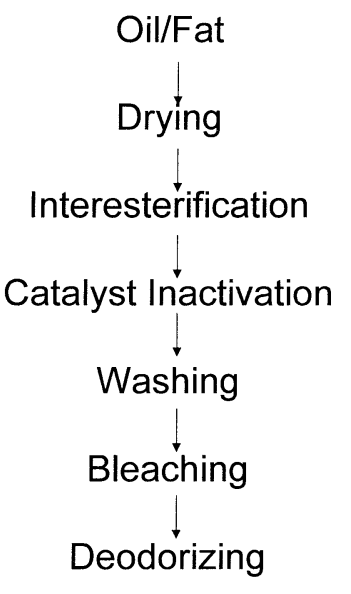

\section{[Chemical process] [Enzymatic process]}

Fig. 4 Processing Flow Chart of Chemical and Enzymatic Interesterification.

して, 従来化学法で行っていたマーガリン, ショートニ ング用油脂への酵素法の利用が進展している。酵素法と 化学法のプロセスを Fig. 4 に示す。

Pedersen らは ${ }^{50)}$, 安価な粒状シリカゲルを担体とし た Thermomyces lanuginosaの固定化リパーゼ （LipozymeTL-IM）を開発した。Zhang ら ${ }^{51)}$ LipozymeTL-IM をパームステアリンとヤシ油のエステ ル交換に用いた場合， $300 \mathrm{~kg}$ のパイロットスケールで 9 バッチ反応しても安定であったことを, DeGreyt ら ${ }^{52)}$ は上記固定化酵素をカラム反応に用いた場合のトータル コストは 40.8 \$ t t であり, 化学法（同 38.0 \$/t）とほぼ 同等であることを報告している。この LiozymeTL-IM を用いたエステル交換プロセスは 2002 年に ADMに よって実用化されている ${ }^{53)}$ 。

一方，国生らは，固定化しなくても微水系でエステル 交換活性が高く，熱安定性の良いAlcaligenes のリパー

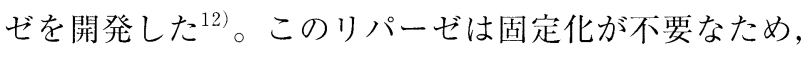
固定化に要するコスト（担体など）と固定化時の活性口 スが削減でき経済的である。この酵素を用いた工業生産 も行われるようになってきている

\section{$4 \cdot 2$ アルコリシスによるバイオディーゼルの製造}

脂肪酸メチルエステルをバイオディーゼル然料として 利用する検討が欧米を中心に行われている。一般的に行 われているアルカリ触媒法では, 油脂中の遊離脂肪酸を 除去する前工程や反応後にグリセリンや石けん成分を水 洗除去する後工程が必要であった。

触媒量の低減や反応後処理の簡略化を目的とした研 究が行われており, $\mathrm{Na} / \mathrm{NaOH}$ を $\gamma-\mathrm{Al}_{2} \mathrm{O}_{3}$ に担持した触 媒 ${ }^{56)}$ ，金属酸化物をイオン交換樹脂に担持した触媒 ${ }^{58)}$, 多孔性㓌イオン交換樹脂 (Diaion PA 306 s) ${ }^{60), 61)}$ 等の固 
体触媒に関する報告, Pseudmonas cepacia のリパーゼ59) を用いる報告等がある。

さらに，触媒を使用しない方法として，Han ら ${ }^{62)}$ は, 大豆油に対して 24 倍量のメタノールと 2.4 倍量の二酸化 炭素を， $280^{\circ} \mathrm{C} ， 14.3 \mathrm{MPa}$ の超臨界状態にした場合，10 分でアルコリシスが完了したことを報告している。ま た，Lawson ら ${ }^{63)}$ は，油脂とアルコールを連続的に直流 で $1,800 \mathrm{~V}$ 以上, 交流で $2,000 \sim 8,000 \mathrm{~V}$ の高電圧で滞留 時間 100 300 msec，温度 $85^{\circ} \mathrm{C}$ ，常圧で処理することで メタノリシスを行ったことを報告し，このとき副生する エーテル化グリセリンはモノアルキルエステルと混和す るため，そのままバイオディーゼル燃料として使用可能 であるとしている。

\section{5 おわりに}

トランス酸の栄養問題やパーム油生産量の拡大, 環境 負荷への配慮など, 油脂産業を取り巻く状況の変化に詨 応した油脂加工技術の開発動向を概説した。

水素添加は低トランス化と高選択性を両立できる方法 が開発されつつある。また，ここでは述べなかったが工 ステル交換原料としての極度硬化油製造も今後の重要な 役割となるであろう。

パーム油の利用拡大に伴い, 分別の重要性は高まって いる。高純度と高収率を両立する効率の良いドライ分別 方法の開発が期待される。

エステル交換は固形脂の機能性を改良する方法として 拡大している。今後は酵素を用いたよりシンプルで低コ ストな方法が主流になる可能性がある。

このような個々の技術の進歩により, 油脂加工技術は これまでの硬化を中心としたものから, 硬化, ドライ分 別，エステル交換を組み合わせたものへと変化していく ことが予想され，今後の研究動向や実用化に向けた技術 展開に注目していきたい。

\section{文献}

1) R.E. Timms, Eur. J. Lipid Sci. Thechnol., 107, 48-57 (2005).

2) 油脂工業史，日本油脂工業会 (1972).

3）食用加工油脂統計年報, 日本マーガリン工業会 (2005).

4）高橋，依田，日本油化学会誌，48, 1141-9 (1999).

5）松本, 日本油化学会誌, 48, 1151-9 (1999).

6) 阿部島, 日本油化学会誌，47, 553-61 (1998).

7) D.A. Allen \& A.C. Manning, Lipds \& Nutrition: Current Hot Topics, PJ Barnes \& Associates, p.105-124 (1996).

8) G.R. List, Lipid Technol., 18, 173-7 (2004).

9) D.E. Pszczola, Food Technol., 58, 52-63 (2004).

10) F.J. Eller, G.R. List, J.A. Teel, K.R. Steidley \& R.O. Adolof, J. Agirc. Food Chem., 53, 5982-4 (2005).
11) V.T. Hans, V. Rossum, J. Gijsbertus \& M.Kruidenberg, USP 2005027136 (2005).

12) P.N. Rylander, J. Am. Oil Chem. Soc., 47, 482-6 (1970).

13) P. Berben, Lipid Technol. Newsletter, Dec. 2002, 133-7 (2002).

14) A. Beers, G, Mangnus, inform, 15, 404-5 (2004).

15) J. Kuiper, EP 0021527 A 1 (1980).

16) B. Nohair, C. Especel, P. Marecot, M. Patrice, H. Claude, L.C. Hoang \& J. Barbier, Comptes Rendus Chimie, 7 , 113-8 (2004).

17) B. Nohair, C. Especel, G. Lafaye, P. Marecot, L.C. Hoang, J. Barbier, J. Mol. Catal., A: Chem., 229, 117-26 (2005).

18) M.B. Fernandez, C.M. Piqueras, G.M. Tonetto, G. Crapiste, D.E. Damiani, J. Mol. Catal., A: Chem., 233, 133-9 (2005).

19) D. Meern, AOCS meeting Abstract, www.aocs.org/ archives/am 2000 ta.htm

20) T. Boger, M. Zieverink, M. Kreutzer, F. Kapteijn, J. Moulijn, W. Addiego, Ind. Eng. Chem. Res., 43, 2337-44 (2004).

21) J. Veldsink, J. Am. Oil Chem. Soc., 78, 443-6 (2001).

22) J. Edvardsson, P. Rautanen, A. Littorin, M. Larsson, J. Am. Oil Chem. Soc., 78, 319 (2001).

23) M. Harrod, WO 96/01304 (1996).

24) E. Ramirez, F. Recasens, M. Fernandez, M. Larrayoz,. AIChE J., 50, 1545-55 (2004).

25) G. Yusen, P.N. Pintauro, J. Am. Oil Chem. Soc., 69, 399-405 (1992).

26) A. Smidnovik, A. Stimac, J. Kobe, J. Am. Oil Chem. Soc., 69, 405-9 (1992).

27) K. Mondal, S. Lalvani, Chem. Eng. Sci., 58, 2643-56 (2003).

28) V. Gibon, A. Tirtiaux, Lipid Technol., March 2002, 33-6 (2002).

29) E. Diffence, Fat Sci. Technol., 89, 502-5-7 (1987).

30) M.L. Herrera, R.W. Hartel, J. Am. Oil Chem. Soc., 77, 1197-204 (2000).

31) D.B. Patience, R.W. Hartel, D. Illimgworth, J. Am. Oil Chem. Soc., 76, 585 (1999).

32) R.W. Hartel, Crystallization Processes in Fats and Lipid Systems, Marcel Dekker, Inc., pp. 381-428 (2001).

33) B. Breitschuh \& E. Floter, Eur. J. Lipid Sci. Technol., 104, 713-9 (2002).

34) R.W. Hartel, WO 98/51753 (1998).

35) 根津, 廣川, 松本, 第 43 回日本油化学会年会講演要旨 集, 134 (2004).

36) R. Krishnamurthy, M. Kellens, Bailey's Industrial Oil \& Fat Products, Vol.4, John wiley \& Sons, Inc., p. 301-37 (1996).

37) K. Weber, T. Homann, T. Willner, Krupp Extraktionstechnik News Letter, Lz 1890 (1997).

38）桑原, 特開 2003-432274 (2003).

39）米田，桶口，谷口，桑原，WO 99/13034 (1999).

40) M. Hendrix, M. Kellens, EP 1282749 A 1 (2003).

41) C.I. Onwulata \& N. Goldberg, J. Am. Oil Chem. Soc., 74, 679-83 (1997). 
42) K. Belkacemi, P. Angers, O. Fischer, J. Arul, Sep. Sci. Technol., 38, 3115-31 (2003).

43) S.P. Erjawetz, J. Ulrich, M. Tiedtke \& R.W. Hartel, J. Am. Oil Chem. Soc., 76, 579-84 (1999).

44) D.G. Wim, IUPAC-AOCS Workshop on Fats, Oils \& Oilseeds Analyses \& Production, lecture summary.

45) M. Harder, C. Alasdair \& R. Macrae, GB 1577933 (1976).

46) F.X. Malcata, H.R. Reyes, H.S. Garcia, C.G. Hill \& C.H. Amundson, J. Am. Oil Chem Soc., 67, 890 (1990).

47) L.C. Chandler, P.T. Quinlan \& G.P. McNeil, J. Am. Oil Chem Soc., 75, 1513 (1998).

48) T. Yamane, T. Suzuki, T. Hosino, J. Am. Oil Chem Soc., 70, 1285 (1993).

49) Sehanputri, PS, Hill J. Biotechnol. Bioeng., 83, 608 (2003).

50) S. Pedersen, A.M. Larsen, P. Aasmul, WO 95/22606 (1995).

51) H. Zhang, X. Xu, J. Nilsson, H. Mu, N.J. Adler \& C.E. Hoy, J. Am. Oil Chem Soc., 78, 57 (2001).

52) W. De Greyt, IUPAC-AOCS Workshop on Fats, Oils \&
Oilseeds Analyses \& Production, lecture summary (2004).

53) BioTimes April 2004, novozymes.

54) S. Negishi, S. Shirasawa, Y. Arai, J. Suzuki \& S. Mukataka, Enzyme Microbial. Technol., 32, 66 (2003).

55）後藤文拫, 鈴木智之, 佐々木俊夫, 館野辰夫, 住友化 学工業(株)研究開発論文, 2001-II, p. 27 (2001).

56) H. Kim, Catalysis Today, 93-95, 315 (2004).

57) F.R. abreu, M.B. Alves, C.C.S. Macedo, L.F. Zara \& P.A.Z. Suarez, J. Molecular Catalysis, 227, 263 (2005).

58) F.R. abreu, M.B. Alves, C.C.S. Macedo, L.F. Zara \& P.A.Z. Suarez, J. Molecular Catalysis, 227, 263 (2005).

59) H. Noureddini, X. Gao \& R.S. Philkana, Bioresource Technol., 96, 769 (2005).

60) 米本年邦, 特願 2004-292212 (2004).

61）米本年邦，特願 2005-198200 (2005).

62) H. Han, W. Cao \& J. Zhang, Process Biochem., 40, 3148 (2005).

63) A.J. Lawson \& A. Baosman, WO 2005046861 (2005). 